\title{
Development of innovative picture storybooks to empower parents and teachers for early childhood education in nutrition and social-behavior in Jakarta
}

\author{
Rina Agustina \\ Department of Nutrition, Faculty of Medicine, Universitas Indonesia, dr.rinaagustina@gmail.com \\ Okky Lupita Sari \\ Department of Nutrition, Faculty of Medicine, Universitas Indonesia
}

See next page for additional authors

Follow this and additional works at: https://scholarhub.ui.ac.id/ajce

Part of the Social and Behavioral Sciences Commons

\section{Recommended Citation}

Agustina, Rina; Sari, Okky Lupita; Sholihah, Lini Anisfatus; Rizqi, Nov; Octavia, Lestari; Pramesthi, Indriya Laras; Prafiantini, Erfi; and Kardha, Putu Chandra Dewi (2018). Development of innovative picture storybooks to empower parents and teachers for early childhood education in nutrition and socialbehavior in Jakarta. ASEAN Journal of Community Engagement, 2(2).

Available at: https://doi.org/10.7454/ajce.v2i2.128

Creative Commons License

\section{(c) (i) ()}

This work is licensed under a Creative Commons Attribution-Share Alike 4.0 License.

This Research Article is brought to you for free and open access by the Universitas Indonesia at ASEAN Journal of Community Engagement. It has been accepted for inclusion in ASEAN Journal of Community Engagement. 


\title{
Development of Innovative Picture Storybooks to Empower
}

\section{Parents and Teachers for Early Childhood Education in Nutrition}

\section{and Social-Behavior in Jakarta}

\author{
Rina Agustinaa,b*, Okky Lupita Saria, Lestari Octaviaa, Lini Anisfatus

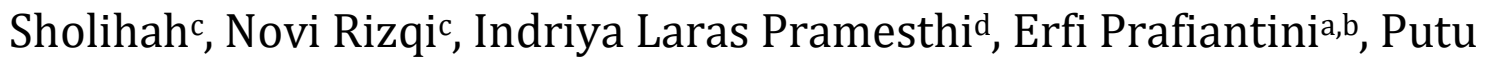 \\ Chandra Dewi Kardhae \\ ${ }^{a}$ Department of Nutrition, Faculty of Medicine, Universitas Indonesia - Dr. Cipto Mangunkusumo General \\ Hospital, Jakarta, Indonesia \\ ${ }^{b}$ Human Nutrition Research Center, Indonesian Medical Education and Research Institute, Faculty of \\ Medicine, Universitas Indonesia \\ 'Division of Human Nutrition, Wageningen University, Wageningen, The Netherlands \\ ${ }^{d}$ Southeast Asian Ministers of Education Organization Regional Centre for Food and Nutrition (SEAMEO \\ RECFON), Jakarta, Indonesia \\ eDepartment of Sociology, Faculty of Social and Political Sciences, Universitas Indonesia, Depok, Indonesia
}

Received: October 12th 2018 || Revised: December $4^{\text {th }}||$ Accepted: December 30th 2018

\begin{abstract}
Indonesia is experiencing a double burden of malnutrition, especially in young children. Many studies show that community empowerment and nutrition education are effective at reducing the risk of malnutrition when combined with attractive tools and appropriate nutrition and parenting messages. Therefore, we developed innovative picture storybooks as a fun learning tool to equip teachers and parents with a way to improve their understanding and awareness of the quality of early childhood dietary habits and social behavior. The study consisted of three stages, including formative research, book development, and evaluation. Our formative research triangulated information on preferences and key messages on food, nutrition, parenting, and child characteristics through focus group discussions (FGDs), in-depth interviews (IDIs), and observations of school food environments. The FGDs were held for the children ( $n=6)$, teachers $(n=6)$, and mothers $(n=6)$. The IDIs explored opinions from a story teller, a nutritionist, a communication expert, a child psychologist, and an illustrator team. Finally, books were developed by the researcher and evaluated by the expert team $(n=10)$ and teachers $(n=8)$. The study took place in early childhood education centers and kindergartens in Central Jakarta's urban areas. Children preferred picture storybooks that represented a unique condition of magical power and provided characters from the fantasy genre. Following the IDI's recommendations and observations, three picture storybook series were developed: healthy snacking, integrated with messages to stimulate a child's disciplined behavior; eating vegetables, especially green ones, with the motivation to increase truthfulness; and a healthy eating portion guide with a variety of foods combined with messages to motivate grateful attitudes. The book content integrated key messages on nutrition, parenting, and social behavior with unique characters and colorful pictures. The expert team recommended the appropriate development of the picture storybooks and emphasized paying attention to clear genres, text structure, content, themes and ideas, language, vocabulary, illustrations and graphic design, and messages delivered. The picture storybooks present key messages on nutrition, parenting, and child behavior using an attractive, colorful and unique appearance. These books can be used to teach early childhood nutrition and parenting intervention by integrating them with other approaches such as story-telling, eating meals together, and other supporting activities.
\end{abstract}

Keywords: fun learning, early childhood nutrition, children character building, urban society, community engagement.

*Correspondence Author: dr.rinaagustina@gmail.com 
Rina Agustina, Okky Lupita Sari, Lini Anisfatuh Sholihah, Novi Rizqi, Lestari Octavia, Indriya Laras Pramesthi, Erfi Prafiantini, Putu Chandra Dewi Kardha | ASEAN Journal of Community Engagement | Volume 2, Number 2, 2018

\section{Introduction}

Indonesia is currently facing a double burden of malnutrition; that is, undernourishment and over-nutrition at the same time. In 2013, the Indonesia Basic Health Survey (Riskesdas) revealed the prevalence of stunting in children under five years old. At the national level, the rate was measured at $37.2 \%$, while the occurrence of overnutrition was 11.9\% (Ministry of Health, 2013). These problems cause stunted conditions and cognitive impairment in children and increase the risk of contracting cardiovascular diseases (CVDs) in the future (de Onis and Branca, 2016; Vasan et al., 2018). In consideration of these facts, efforts should be made to reduce the future risk of disease (DeBoer, 2013; Guerrant et al., 2013), especially the occurrence of non-communicable diseases that would affect the work performance and quality of life (DeBoer, 2013; Bhutta et al., 2013).

Consumption of fruits and vegetables by Indonesian children is below the recommended amount of 5 portions (400 g) in one week. 93.6\% of children under 10 years old received insufficient of dietary fibers (Ministry of Health, 2007), while the study on benefit of fiber was clearly explained its role in reducing the risk of the chronic disease (Edwards et al., 2015). A systematic review of school-based intervention to improve these conditions mentioned that the low consumption of fruits and vegetables was caused by limited availability and accessibility, taste preferences, lack of family support, lack of knowledge, and lack of verbal praise (Evans et al., 2012). On the other hand, obesity is another phenomenon found nowadays that its trend was slightly increased from year to year (Zeba et al., 2014; Rachmi et al., 2016; Office, 2013). The coexistence of malnutrition, under and over nutrition, as this problem is recognized as a double burden of malnutrition requires a new approach in educating the communities within the region (Mahmudiono et al., 2016). The identifiable causes of these findings are the unequal distribution of income in the region, urbanization and the access to unhealthy diet (Sekiyama et al., 2015; Hanandita and Tampubolon, 2015; El Kishawi et al., 2016). It therefore becomes crucial to develop tools to improve the quality of knowledge to ensure the dietary practices and social behavior improvement in daily life activities.

Poor nutrition knowledge is one of factors that contribute to the persistent of malnutrition (Cruz et al., 2017). The poor knowledge of mothers and/or caregivers on feeding practices will come with the prevailed malnutrition in growth and development period (Mahmudiono et al., 2016). The improvement of their knowledge will provide the 
Rina Agustina, Okky Lupita Sari, Lini Anisfatuh Sholihah, Novi Rizqi, Lestari Octavia, Indriya Laras Pramesthi, Erfi Prafiantini, Putu Chandra Dewi Kardha | ASEAN Journal of Community Engagement | Volume 2, Number 2, 2018 proper knowledge in serving meal for the children (Inayati et al., 2012). Many approaches have been implemented to promote healthy diets. Some intervention programs in Europe promoted health improvement by changing children's exposure to the media. These programs endorsed children having less accessibility to media to avoid seeing unhealthy food advertisements (Capacci et al., 2012).

The other effort uses an interesting media, like story telling is challenging (Haigh and Hardy, 2011). Parent-children interaction in storytelling session is believed as one of the encouragements for the children to develop their ability to read (Baker et al., 2001). Story telling is recognized as one effective strategy for spreading a healthy life style and motivating the target group. Games, visualization and simulation have all proven beneficial in improving clinical outcomes. A study of Latino American parents and their children showed that an Interactive Cause and Effect Comic-book Storytelling (ICECS) intervention program improved knowledge regarding healthy diet, nutrition, and exercise, and promoted parent-child communication. This study complemented the learning process and improved knowledge sharing by using a mobile application (Amresh et al., 2015). Study in American Indian and Alaska Native addressed the benefit of storytelling in delivering the health message to the children. Utilizing the storytelling will facilitate the knowledge transfer and communication of core values and belief system to target group (Heaton et al., 2018). Story telling using picture books is a low-cost method of increasing the engagement by the caregiver and the children. These studies showed that community empowerment and nutrition education were effective when combined with appropriate nutrition topics and parenting messages within attractive tools in the effort to reduce the risk of malnutrition (Donna Winham, 2013; Amresh et al., 2015).

Community empowerment is more than the involvement, participation or engagement of communities. It recognizes that if some people are going to be empowered, then others will be sharing their existing power. Communication plays a vital role in ensuring community empowerment. Participatory approaches in communication that encourage discussion result in increased knowledge and awareness, and a higher level of critical thinking. Critical thinking enables communities to understand the interplay of forces operating on their lives, and helps them take their own decisions (WHO, 2019). A community is structured to have five functions (Warren, 1983 in Berns, 2010) namely 1) Production, distribution, consumption. 2) Socialization. 3) Social control. 4) Social 
Rina Agustina, Okky Lupita Sari, Lini Anisfatuh Sholihah, Novi Rizqi, Lestari Octavia, Indriya Laras Pramesthi, Erfi

Prafiantini, Putu Chandra Dewi Kardha | ASEAN Journal of Community Engagement | Volume 2, Number 2, 2018 participation. 5) Mutual support. Communities, small or large, perform these functions in many different ways, which can influence the socialization of children growing up there (Berns, 2010).

Therefore, in our present study, we developed innovative picture storybooks as fun learning tools to equip teachers and parents with an improved understanding and awareness on the quality of early childhood dietary habits and social behaviors. It is important to define appropriate tools in delivering the message for the target group to enrich the acceptance from the population. For children, elaborating an interesting program is even challenging due to the complexity of the problem identified and simplicity of the message to be addressed and delivered.

\section{Methods}

By 2016, the Department of Nutrition, Faculty of Medicine, Universitas Indonesia (FMUI) together with the local government (Senen sub-district office) and the Southeast Asian Ministers of Education Organization Regional Centre for Food and Nutrition (SEAMEO-RECFON) had initiated the pilot program to develop a nutrition education module and fun learning program for pre-school children entitled "CERIA" CERdas, bergizI dan Aktif (smart, well-nourished and active). The initial products used in the program were a TV flipchart, nutrition module and food guideline "a tumpeng game" using socio-ecological approach for the kindergarten and early childhood education ("PAUD" Pendidikan Anak Usia Dini). In 2017, together with the Human Nutrition Research Center, Indonesian Medical Education and Research Institute (HNRC-IMERI), and Doctorate Study Program In Nutrition, FMUI the program continued by developing a new innovative tool, CERIA picture storybooks, to complement the fun learning program.

To come up with appropriate picture storybooks to teach early childhood nutrition and behavior, we conducted the study by involving the children, parents, and school teachers in early childhood education centers and kindergartens in some areas of Central Jakarta, Indonesia. As adapted from Gall et al. (2007), the research and development steps for creating the education media were: preliminary study to collect data, planning and development of the picture storybook drafts, field trials, and dissemination.

This study was divided into three stages, including formative research, book development, and evaluation. The outlines of the current study were: formative research 
Rina Agustina, Okky Lupita Sari, Lini Anisfatuh Sholihah, Novi Rizqi, Lestari Octavia, Indriya Laras Pramesthi, Erfi Prafiantini, Putu Chandra Dewi Kardha | ASEAN Journal of Community Engagement | Volume 2, Number 2, 2018 with FGDs and IDIs, observation of school food environments, picture storybook development, and expert team evaluation.

\subsection{Focus Group Discussions (FGDs)}

Formative research began with organizing FGDs with the teachers, parents, and children. The first group consisted of students $(n=6)$. The second group consisted of teachers $(n=6)$ and mothers $(n=6)$ as representatives from two targeted schools. The students who were involved in the discussion were in the second grade of kindergarten or early childhood education class, so they were already able to read. The parents and students who were involved in the FGDs were already familiar with storytelling and/or reading books.

Through FGDs, the researchers gathered information to develop picture storybooks that were suited for children and that they would like. The discussions were designed to gain information from teachers, parents, and children regarding the following outcomes: 1) To learn the children's reading habits; 2) To understand the types of picture storybooks children like; 3) To understand the characteristics of picture storybooks for children; and 4) To learn the aspects of character building and nutritional messages best suited for children.

The desirable aspects of children's preferences for picture storybooks were explored. The delivered messages were also investigated. The questions asked of the children were as follows: (a) What is the character that they like the most from the picture storybook? (b) What is the genre fantasy that they like the most from the picture storybook? (c) What is the storyline that they like the most from the picture storybook? and (d) What are the picture storybook components (characterization, theme, plot, color, and layoutthat they like the most? The teachers and parents were asked similar questions, with added inquiries as follows: (a) What are the current important messages (both for nutrition education and character building) that the children need the most, considering their age and social background? and (b) How can the picture storybook work most effectively to educate the children?

We also asked for opinions about the important messages (both in nutrition and character-building aspects) that needed to be delivered to children through the development of these picture storybooks. Specifically, we identified current nutrition and 
Rina Agustina, Okky Lupita Sari, Lini Anisfatuh Sholihah, Novi Rizqi, Lestari Octavia, Indriya Laras Pramesthi, Erfi Prafiantini, Putu Chandra Dewi Kardha | ASEAN Journal of Community Engagement | Volume 2, Number 2, 2018 eating problems among the children as the focus of the messages to deliver. Based on our understanding of those problems, we then asked how parents' and teachers' expectations could be improved through reading picture storybooks.

\subsection{In depth interviews (IDIs)}

In depth interviews were held with the following experts: a storyteller, a nutritionist, a communication expert, a child psychologist, and an illustrator. The interviews were guided by questions based on their individual expertise. Questions for the storyteller focused on how the story line should be created. The nutritionist was interviewed about children's nutritional requirements, nutritional knowledge, and types of nutritional intervention to help overcome the eating problem among children. For the communication expert, the questions focused on the components of the picture storybook (e.g. characterization, theme, plot, color, font, and picture) and how to translate the nutritional message and character building into the picture storybook. For the child psychologist, we are focused on the discussion on child characteristics and development, and suitable characteristics of picture storybooks with nutrition education and character building for kindergarten-aged children and early childhood education. Lastly, we explored the design of picture storybooks during our interview of the illustrator.

All IDIs were conducted by two people and were recorded. One person asked the questions while the other ensured that recording tools were ready for all questions and answers. After making sure that all questions were asked, the second person could also ask additional questions to clarify answers or probe for more information if necessary. The recorded IDIs were then summarized.

\subsection{Observation of food environment at school}

Because the habit of consuming snacks and foods from vendors already existed in the community, we observed which food vendors were commonly found in the areas surrounding the schools. Food safety and variety were the main observations raised. 


\subsection{Development of picture storybooks}

Efforts were made develop the picture storybooks by involving experts from fields. To draft picture storybooks containing complete storylines and specific descriptions of characters and settings, we brainstormed with an expert children storyteller. We finally decided to create the picture storybook in three series, each with different storylines and messages, but all with similar main characters and genres.

Once the first draft was finished, we delivered it to the graphic designer and illustrator. Next, the graphic designer translated the draft text into a sketch. Before the initial evaluation, we revised the picture storybook sketch created by the graphic designer. The aspects that we revised from the sketch included the choice of pictures, language, and story content. After that, the graphic designer made revisions based on those suggestions.

\subsection{Evaluated by the expert team}

We performed an initial evaluation with several experts: a child psychologist, a nutritionist, a literacy specialist, physicians, and a communication expert. They reviewed the first revision of the picture storybook. Their reviews were used to improve the picture storybook before delivering it to the children.

\section{Result and Discussion}

Briefly, the development of the picture storybook underwent three main steps: formative research, picture storybook development, and evaluation, as seen in Figure 1. 
Rina Agustina, Okky Lupita Sari, Lini Anisfatuh Sholihah, Novi Rizqi, Lestari Octavia, Indriya Laras Pramesthi, Erfi Prafiantini, Putu Chandra Dewi Kardha | ASEAN Journal of Community Engagement | Volume 2, Number 2, 2018

\begin{tabular}{|l|l|}
\hline \multicolumn{2}{|c|}{$\mathbf{1}^{\text {st }}$ stage (formative research) } \\
\hline $\begin{array}{l}\text { Activities: Focus Group } \\
\text { Discussions, In-depth Interviews, } \\
\text { observation of food environment }\end{array}$ & $\begin{array}{l}\text { Resources person: children, teacher, mother, } \\
\text { storyteller, nutritionist, communication expert, child } \\
\text { psychologist and illustrator team }\end{array}$ \\
\hline Result: point or content of picture storybook \\
\hline $\begin{array}{l}\text { Activities: derivation of previous } \\
\text { part idea and transformation in } \\
\text { picture storybook }\end{array}$ & $\begin{array}{l}\text { Resources person: graphic designer, researcher, child } \\
\text { psychologist }\end{array}$ \\
\hline Result: three series of picture storybooks \\
\hline $\begin{array}{l}\text { Activities: the appropriateness of } \\
\text { picture storybook with nutrition } \\
\text { and behavior content }\end{array}$ \\
\hline $\begin{array}{l}\text { Result: recommendation of picture book related to genre, text structure, content, theme and } \\
\text { ideanguage, vocabulary, illustration and book graphic design, and message delivered } \\
\text { literacy specialist, physicians and communication } \\
\text { expert }\end{array}$ \\
\hline
\end{tabular}

Figure 1. The stages of research

\subsection{Focus group discussion}

Children preferred the picture storybook with illustrations of magical power and fantasy genre characters. The summary of concepts used in the picture storybook can be seen in Table 1.

Table 1. The concept of each aspect of the picture storybook derived from the results of Focus Group Discussions and In-depth Interviews

\begin{tabular}{cll}
\hline No. & \multicolumn{1}{c}{ Aspect } & \multicolumn{1}{c}{ Concept } \\
\hline 1. & Main & - People with magical powers \\
& characters & -Consists of male and female characters. \\
2. & Genre & Fantasy \\
3. & Storyline & Daily life \\
4. & Other & -Picture should be dominant in the book. \\
& components & - Less text, one page consists of \\
& & maximum 4 sentences/lines.
\end{tabular}


Rina Agustina, Okky Lupita Sari, Lini Anisfatuh Sholihah, Novi Rizqi, Lestari Octavia, Indriya Laras Pramesthi, Erfi Prafiantini, Putu Chandra Dewi Kardha | ASEAN Journal of Community Engagement | Volume 2, Number 2, 2018

No.

Aspect

Concept

\begin{tabular}{|c|c|c|}
\hline & & -Attractive title \\
\hline & & -Bright color of layout \\
\hline & & -Attractive story \\
\hline & & -Less patronizing \\
\hline & & \multirow{2}{*}{$\begin{array}{l}\text {-Appropriate messages (no violence and } \\
\text { no transgender issue) }\end{array}$} \\
\hline & & \\
\hline \multirow[t]{4}{*}{5.} & Nutrition & Healthy snacks \\
\hline & messages & - $\quad$ Eating vegetables, especially green \\
\hline & & vegetables \\
\hline & & - $\quad$ My healthy eating plate \\
\hline \multirow[t]{3}{*}{6.} & Character & -Discipline \\
\hline & building & -Honest \\
\hline & & -Grateful \\
\hline
\end{tabular}

\subsection{In depth interview}

\subsubsection{Child psychologist}

Based on the interview of the child psychologist, a young child's psychomotor ability is still immature, so they are not able to concentrate on one thing. Therefore, the picture storybook should focus on cognitive aspects that helped children to understand the story and to learn it directly. Moreover, the psychologist thought that the story telling method and the characters were critical for developing the picture storybook. The characters which are usually used for children's books were fables (animal characters), fantasy, and human figures. The story telling method should also be delivered with a good accent and articulation. The storyline should use persuasive words and affect the children's emotions.

The present books have been developed with these character-building attributes: discipline, independence, integrity, honesty, and gratitude. 


\subsubsection{Nutritionist}

The nutritionist emphasized delivering several key messages to children and parents. Children should know the benefit of nutrients from early childhood, including carbohydrates, protein, fat, and vitamins and minerals. The caregivers and mothers should support healthy dietary habits by providing diversified food at each meal so that the children learn to consume more diversified food. Parents should be good role models in their eating habits, and they should stimulate children to not be picky eaters; this problem is commonly found due to less disciplined behavior by parents. Parents should also have adequate financial management skills to manage the family budget to provide healthy and nutritious foods. Besides, mothers should understand how to fulfill the children's dietary requirements and avoid urging children to eat a lot. Finally, the nutritionist suggested that optimal nutrition intervention could be achieved through cooperation between teachers and parents. In addition, psychologists could also play a role in educating parents on how to be more disciplined in their parenting behavior, such as meal scheduling and provision of food variety, especially if other caretakers are involved (such as grandmothers, housemaids, etc.).

\subsubsection{Communication expert}

The communication expert focused on the purpose of changing points, whether in knowledge or behavior. In the process of developing a picture storybook, the creators should brainstorm and then collect references to ensure that new ideas have never existed before. Creating a storyline and determining the characters to be translated into the storyboard were considered important initial steps. Then the frames of the story and pictures had to be adjusted to allow children to receive the messages. Based on one suggestion, the picture storybook was created in limited amount but high in quality. The decision also needed to be made whether the books would be placed only at school or at home as well. For the books to successfully attract children, the expert suggested that the books should be colorful that it use taglines with simple words.

The summary of experts' opinion was delivered in table 2. 
Rina Agustina, Okky Lupita Sari, Lini Anisfatuh Sholihah, Novi Rizqi, Lestari Octavia, Indriya Laras Pramesthi, Erfi Prafiantini, Putu Chandra Dewi Kardha | ASEAN Journal of Community Engagement | Volume 2, Number 2, 2018

Table 2. The opinion from the expert involved in the study on picture storybook

\begin{tabular}{ll}
\hline Expertise & Opinion \\
\hline Child psychologist & $\begin{array}{l}\text { It is important to choose the correct characters that will } \\
\text { stimulate the cognitive development of the children }\end{array}$ \\
Nutritionist & The key messages of the picture storybooks should consider \\
& the recipient, namely: children, parents, teachers, and care \\
& givers. The message driven must be clearly understood by \\
& those targets. \\
& The message delivered must be concise, in short sentence, \\
Communication & straight and easy to understand and memorize.
\end{tabular}

\subsection{Development of picture storybooks}

The main characters preferred by children were figures with magical powers. To create picture storybooks intended for both male and female readers, we developed two characters with magical powers: a girl and a boy. These main characters were named "Pula" (boy) and "Pili" (girl). The origin of these names was the Indonesian word pulau, meaning "island". The term pulau was used to remind children that Indonesia is an archipelago country consisting of thousands of islands to strengthen their pride in the nation. Pula's magical power is archery using fish thorn. Pula as described as a smart prince from the Tropical Wind Kingdom who loves eating fish. While Pula's sister Pili is a princess who loves fruit and vegetables and can call the storm. 
Rina Agustina, Okky Lupita Sari, Lini Anisfatuh Sholihah, Novi Rizqi, Lestari Octavia, Indriya Laras Pramesthi, Erfi Prafiantini, Putu Chandra Dewi Kardha | ASEAN Journal of Community Engagement | Volume 2, Number 2, 2018

Table 3. Three series of pictures storybook developed based on the results of focus group discussions, in-depth Interviews and design concept by graphic designers

\begin{tabular}{lllll}
\hline Series & Cover Color & Main Figure & $\begin{array}{l}\text { Nutrition } \\
\text { Aspect }\end{array}$ & Character Aspect \\
\hline 1 & Yellow & Monster Jaja & Healthy snacking & $\begin{array}{l}\text { Discipline and } \\
\text { independence }\end{array}$ \\
& & & \\
& Blue & Merah Matahari & Eating vegetables & Integrity and honesty \\
& & Kelinci & \\
& & & \\
& & Pula and Pili & Healthy eating & Grateful messages \\
& & plate & \\
\hline
\end{tabular}

The CERIA picture storybooks were divided into three series, each containing different messages and storylines but with the same main characters and genres. The first series contained healthy snacking education which was integrated with disciplinary messages. The second series was about eating vegetables, especially the green ones. Based on FGDs involving mothers and teachers, we found that children tended to avoid eating green vegetables because they disliked the smell and taste. Therefore, in the second series, we engaged children to eat green vegetables and suggested that their mothers prepare vegetables using various delicious methods throughout the attractive story.

We also inserted messages meant to build children's integrity and honesty. For example, if they disliked and did not finish their food, they could inform their mother honestly instead of throwing the food away. The last series talked about the healthy eating plate and had messages of gratitude integrated throughout. At the end of the book, we included some explicit messages summarizing the whole story for parents. Mothers and teachers could use these to deliver the messages clearly to the children.

This study supports the theory that including character education can teach children about the quality and traits of good character. It deals with teaching children to develop the ability to decide how to behave in an appropriate manner in various social situations with the purpose of developing individuals who are capable of understanding moral 
Rina Agustina, Okky Lupita Sari, Lini Anisfatuh Sholihah, Novi Rizqi, Lestari Octavia, Indriya Laras Pramesthi, Erfi Prafiantini, Putu Chandra Dewi Kardha | ASEAN Journal of Community Engagement | Volume 2, Number 2, 2018 values and who choose to do the right thing (Almerico, 2014). The content of character education typically aligns with the core principles and values of generosity, kindness, honesty, tolerance, trust, integrity, loyalty, fairness, freedom, equality, and respect of and for diversity (Bohlin, Farmer, \& Ryan, 2001; Brooks, 2001). Other study also revealed that school-based efforts which promote students' social and emotional learning produced a positive impact on academic learning and increasing achievement test scores. This indicates schools with effective character education programs can enhance a child's success both in school and in life (Durlak et al., 2011).

\subsection{Experts evaluation}

Expert team had provided recommendations that the picture storybooks should pay attention on genre, text structure, content, theme and idea, language, vocabulary, illustration and book graphic design and messages delivered, with some suggestions to improve the storybooks. The team suggested to not writing up the storylines that were already illustrated on the pictures. For example, if there was a picture of a child on a boat, the team should not describe this picture to the text anymore. The reason that the right brain of children connected to imagination and visualization (picture and color). By having least text explaining the pictures, children could use their imaginations during readings the picture storybooks. In drawing the animation in the picture storybooks, the team should use painting techniques instead of computers to avoid the visual literacy acceleration. Children should also receive basic literacy which explained that how they used their smell, sight and taste. Furthermore, children could learn from experience based on environment. The use of rhymes in words was very necessary. In this recent picture storybooks, there was word of "Tana-Tana" which was easily said by children. This books also can potentially be used as a speech therapy for children. For the further development, the team also suggested that the team should develop a guideline which can be used by teachers and mothers to accompany children in reading picture storybooks.

This study revealed the necessity of usage the acceptable method for target group perceived. The storybook contained interesting picture, simple plot and attractive message could benefit the program delivered (Baker et al., 2001). Similar finding was found in Indonesia on campaigning the clean and healthy lifestyle, it implies the benefit of taking the impressive way for under five years old children by utilizing the storybook 
Rina Agustina, Okky Lupita Sari, Lini Anisfatuh Sholihah, Novi Rizqi, Lestari Octavia, Indriya Laras Pramesthi, Erfi

Prafiantini, Putu Chandra Dewi Kardha | ASEAN Journal of Community Engagement | Volume 2, Number 2, 2018 (Hasni and Fajri, 2018). Image is important for under- five year old children to construct the creative thinking, not only interesting but also instructive for this particular group. Furthermore, book would assist in understanding complex subject with rich explanatory method (Kelemen et al., 2014).

In the construction the storybook, the involvement of experts was mandatory. The participation of nutritionist, child psychologist, communication, teacher, parents of the children enriched the content of the book. Since the main target of the book was the children, engaging parents and teacher is crucial. As the mediators, they should be able to recognize the point of the book, with effective communication between childcare providers or teachers and parents (Dev et al., 2017).

\section{Conclusion}

Three series of picture story-books were developed in three steps, namely formative research, picture storybook development and evaluation. These books were adjusted to the unique magical power theme and fantasy characters preferred by children, and presented in big picture size, colorful with few texts. These book series contained messages with themes on healthy snacking education to stimulate self-discipline; vegetable consumption with encouragement to raise honesty; food variety and healthy eating encouraging expression of gratitude. Expert team advised that the books have been appropriately developed, and to focus on clear genre, text- structure, content, theme, language, vocabulary, illustration, design, and messages delivered. Future early childhood and parenting interventions are encouraged to use these books by integrating it with storytelling, having meal together and other fun activities.

\section{Acknowledgements}

This research was funded by Kemristekdikti Republik Indonesia (The Ministry of Research Technology and Higher Education, Republic of Indonesia) in Pengabdian Masyarakat (Community Engagement) scheme, with in-kind contribution from Human Nutrition Research Center-Indonesian Medical Education and Research Institute (HNRCIMERI), and Doctorate Study Program in Nutrition Faculty of Medicine Universitas Indonesia. SEAMEO RECFON (Southeast Asian Ministers of Education Organization Regional Centre for Food and Nutrition) was also participated in funding the printing of 
Rina Agustina, Okky Lupita Sari, Lini Anisfatuh Sholihah, Novi Rizqi, Lestari Octavia, Indriya Laras Pramesthi, Erfi Prafiantini, Putu Chandra Dewi Kardha | ASEAN Journal of Community Engagement | Volume 2, Number 2, 2018 picture storybook..

\section{References}

Almerico, G. M. 2014. Building character through literacy with children's literature. Research in Higher Education Journal, 26, 1-13.

Amresh, A., Sinha, M., Birr, R. \& Salla, R. 2015. Interactive Cause and Effect Comic-book Storytelling for Improving Nutrition Outcomes in Children. Proceedings of the 5th International Conference on Digital Health 2015 - DH '15.

Baker, K. M., Sonnenschein, S., Serpell, R. 2001. Parents' Interactions with Their FirstGrade Children During Storybook Reading and Relations with Subsequent Home Reading Activity and Reading Achievement. Journal of School Psychology, 39 no 5, 415-438.

Berns, Roberta M. 2010. Child, Family, School, Community: Socialization and Support. $8^{\text {th }}$ Edition. Belmont. Wadsworth, Cengage Learning.

Bhutta, Z. A., Salam, R. A. \& Das, J. K. 2013. Meeting the challenges of micronutrient malnutrition in the developing world. Br Med Bull, 106, 7-17.

Bohlin, K.D., Farmer, \& Ryan, K. 2001. Building character in schools resource guide. San Francisco, CA: Jossey-Bass.

Capacci, S., Mazzocchi, M., Shankar, B., Macias, J. B., Verbeke, W., Perez-Cueto, F. J., KoziolKozakowska, A., Piorecka, B., Niedzwiedzka, B., D'addesa, D., Saba, A., Turrini, A., Aschemann-Witzel, J., Bech-Larsen, T., Strand, M., Smillie, L., Wills, J. \& Traill, W. B. 2012. Policies to promote healthy eating in Europe: a structured review of policies and their effectiveness. Nutr Rev, 70, 188-200.

Cruz, L. M. G., Azpeitia, G. G., Suarez, D. R., Rodriguez, A. S., Ferrer, J. F. L. \& Serra-Majem, L. 2017. Factors Associated with Stunting among Children Aged 0 to 59 Months from the Central Region of Mozambique. Nutrients, 9.

De Onis, M. \& Branca, F. 2016. Childhood stunting: a global perspective. Matern Child Nutr, 12 Suppl 1, 12-26.

Deboer, M. D. 2013. Obesity, systemic inflammation, and increased risk for cardiovascular disease and diabetes among adolescents: a need for screening tools to target interventions. Nutrition, 29, 379-86. 
Rina Agustina, Okky Lupita Sari, Lini Anisfatuh Sholihah, Novi Rizqi, Lestari Octavia, Indriya Laras Pramesthi, Erfi Prafiantini, Putu Chandra Dewi Kardha | ASEAN Journal of Community Engagement | Volume 2, Number 2, 2018

Dev, D.A., Byrd-Williams, C., Ramsay, R., McBride, B., Srivastava, D., Murriel, A., Arcan, C., and Adachi-Mejia, A.M. 2017. Engaging Parents to Promote Children's Nutrition and Health: Providers' Barriers and Strategies in Head Start and Child Care Centers. American Journal of Health Promotion, 31(2), 153-162.

Donna Winham, S. S. Q., Tamara Underiner, Stephani Woodson, And Megan Todd. 2013. Nutrition education integrates culture via storytelling in cooking workshop for community nutritionists.

Durlak, J. A., Weissberg, R. P., Dymnicki, A. B., Taylor, R. D. \& Schellinger, K. B. 2011, The Impact of Enhancing Students' Social and Emotional Learning: A Meta-Analysis of School-Based Universal Interventions. Child Development, 82. 405-432.

Edwards, C. A., Xie, C. \& Garcia, A. L. 2015. Dietary fibre and health in children and adolescents. Proc Nutr Soc, 74, 292-302.

El Kishawi, R. R., Soo, K. L., Abed, Y. A. \& Wan Muda, W. A. 2016. Prevalence and Associated Factors for Dual Form of Malnutrition in Mother-Child Pairs at the Same Household in the Gaza Strip-Palestine. PLoS One, 11, e0151494.

Evans, C. E., Christian, M. S., Cleghorn, C. L., Greenwood, D. C. \& Cade, J. E. 2012. Systematic review and meta-analysis of school-based interventions to improve daily fruit and vegetable intake in children aged 5 to 12 y. Am J Clin Nutr, 96, 889-901.

Gall, M., Gall, J., and Borg, W. 2007. Educational research: An introduction, $8^{\text {th }}$ Edition. New York and London: Longman.

Guerrant, R. L., Deboer, M. D., Moore, S. R., Scharf, R. J. \& Lima, A. A. 2013. The impoverished gut--a triple burden of diarrhoea, stunting and chronic disease. Nat Rev Gastroenterol Hepatol, 10, 220-9.

Haigh, C. \& Hardy, P. 2011. Tell me a story--a conceptual exploration of storytelling in healthcare education. Nurse Educ Today, 31, 408-11.

Hanandita, W. \& Tampubolon, G. 2015. The double burden of malnutrition in Indonesia: Social determinants and geographical variations. SSM Popul Health, 1, 16-25.

Hasni, F. Y. \& Fajri, I. N. 2018. The combination of storybook and children's activity: “The seven basic principles of a clean and healthy lifestyle". IOP Conference Series: Materials Science and Engineering, 453.

Heaton, B., Gebel, C., Crawford, A., Barker, J. C., Henshaw, M., Garcia, R. I., Riedy, C. \& Wimsatt, M. A. 2018. Using Storytelling to Address Oral Health Knowledge in 
Rina Agustina, Okky Lupita Sari, Lini Anisfatuh Sholihah, Novi Rizqi, Lestari Octavia, Indriya Laras Pramesthi, Erfi Prafiantini, Putu Chandra Dewi Kardha | ASEAN Journal of Community Engagement | Volume 2, Number 2, 2018

American Indian and Alaska Native Communities. Prev Chronic Dis, 15, E63.

Inayati, D. A., Purwesti, R. C., Wirawan, N. N., Suryantan, J., Hartono, S., Bloem, M. A., Pangaribuan, R. V., Biesalski, H. K., Hoffmann, V., Bellows, A. C. 2012. Improved nutrition knowledge and practice through intensive nutrition education: A study among caregivers of mildly wasted children on Nias Island, Indonesia. Food and Nutrition Bulletin, vol. 33, no. 2, 117-127.

Kelemen, D., Emmons, N. A., Seston Schillaci, R. \& Ganea, P. A. 2014. Young children can be taught basic natural selection using a picture-storybook intervention. Psychol Sci, $25,893-902$.

Mahmudiono, T., Nindya, T. S., Andrias, D. R., Megatsari, H. \& Rosenkranz, R. R. 2016. The effectiveness of nutrition education for overweight/obese mothers with stunted children (NEO-MOM) in reducing the double burden of malnutrition in Indonesia: study protocol for a randomized controlled trial. BMC Public Health, 16, 486.

Ministry of Health Republic of Indonesia. 2007. Report on national basic health research (RISKESDAS). Jakarta: The National Institute of Health Research and Development (NIHRD).

Ministry of Health Republic of Indonesia. 2013. Report on national basic health research (RISKESDAS). Jakarta: The National Institute of Health Research and Development (NIHRD).

Office, T. W. B. 2013. The double burden of malnutrition in Indonesia.

Rachmi, C. N., Agho, K. E., Li, M. \& Baur, L. A. 2016. Stunting, Underweight and Overweight in Children Aged 2.0-4.9 Years in Indonesia: Prevalence Trends and Associated Risk Factors. PLoS One, 11, e0154756.

Sekiyama, M., Jiang, H. W., Gunawan, B., Dewanti, L., Honda, R., Shimizu-Furusawa, H., Abdoellah, O. S. \& Watanabe, C. 2015. Double Burden of Malnutrition in Rural West Java: Household-Level Analysis for Father-Child and Mother-Child Pairs and the Association with Dietary Intake. Nutrients, 7, 8376-91.

Vasan, S. K., Roy, A., Samuel, V. T., Antonisamy, B., Bhargava, S. K., Alex, A. G., Singh, B., Osmond, C., Geethanjali, F. S., Karpe, F., Sachdev, H., Agrawal, K., Ramakrishnan, L., Tandon, N., Thomas, N., Premkumar, P. S., Asaithambi, P., Princy, S. F. X., Sinha, S., Paul, T. V., Prabhakaran, D. \& Fall, C. H. D. 2018. IndEcho study: cohort study investigating birth size, childhood growth and young adult cardiovascular risk 
Rina Agustina, Okky Lupita Sari, Lini Anisfatuh Sholihah, Novi Rizqi, Lestari Octavia, Indriya Laras Pramesthi, Erfi Prafiantini, Putu Chandra Dewi Kardha | ASEAN Journal of Community Engagement | Volume 2, Number 2, 2018 factors as predictors of midlife myocardial structure and function in South Asians. BMJ Open, 8, e019675.

WHO. 2019. Track 1: Community empowerment. 7th Global Conference on Health $\begin{array}{llll}\text { Promotion: } & \text { Track themes. Accessed from }\end{array}$ https://www.who.int/healthpromotion/conferences/7gchp/track1/en/

Zeba, A. N., Delisle, H. F. \& Renier, G. 2014. Dietary patterns and physical inactivity, two contributing factors to the double burden of malnutrition among adults in Burkina Faso, West Africa. J Nutr Sci, 3, e50. 